\title{
How to use composite indicator and linear programming model for determine sustainable tourism
}

\author{
Maryam Ziaabadi ${ }^{*}$, Mohammad Malakootian², Mohammad Reza Zare Mehrjerdi ${ }^{3}$, Seied Abdolmajid Jalaee ${ }^{4}$ \\ and Hosein Mehrabi Boshrabadi ${ }^{5}$
}

\begin{abstract}
Background: The tourism industry which is one of the most dynamic economic activities in today's world plays a significant role in the sustainable development. Therefore, in addition to paying attention to tourism, sustainable tourism must be taken into huge account; otherwise, the environment and its health will be damaged irreparably.

Methods: To determine the level of sustainability in this study, indicators of sustainable tourism were first presented in three environmental health, economic and social aspects. Then, the levels of sustainable tourism and environmental sustainability were practically measured in different cities of Kerman Province using a composite indicator, a linear programming model, Delphi method and the questionnaire technique. Finally, the study cities (tourist attractions) were ranked.

Results: Result of this study showed that unfortunately the tourism opportunities were not used appropriately in these cities and tourist destinations, and that environmental aspect (health and environmental sustainability) had very bad situations compared to social and economic aspects. In other words, environmental health had the lowest levels of sustainability.

Conclusions: The environment is a place for all human activities like tourism, social and economic issues; therefore, its stability and health is of great importance. Thus, it is necessary to pay more attention to sustainability of activities, management and environmental health in planning sustainable development in regional and national policy.
\end{abstract}

Keywords: Sustainable development, Environmental health, Sustainable indicators, Linear programming model, Tourism

\section{Background}

Sustainable tourism is one of the criteria of sustainable development. The tourism industry is considered the biggest and the most diverse industry in the world [1]. Total number of international tourists increased from 25 million in 1950 to 903 million in 2007; the income resulted from this activity reached 865 billion dollars. It is predicted that the total number of tourists will be 1.6 billion people in 2020 [2]. Tourism is a nice experience for visitors and causes employment, income and other

\footnotetext{
* Correspondence: mziaabadi@gmail.com

${ }^{1}$ Economics of natural resources and Environment, Shahid Bahonar University of Kerman, Kerman, Iran

Full list of author information is available at the end of the article
}

benefits for the host community. However, if it is planned or managed inappropriately, it could be a disaster for visitors, the tourism destination and the host community. If the natural or culture environment is damaged or if tourism acts poorly, people lose their positive energy to stabilize and enrich the environment $[3,4]$. Sustainable tourism requires systematic attention to environmental, social- cultural and economic aspects so as to use tourist attractions proportional to today's needs and preservation of future resources [5].

The aim of sustainable tourism is to improve the life quality of host societies, keep equality and justice between two generations and within a generation, maintain the quality of the environment by protecting the 
ecological system, maintain cultural integrity and social solidarity between communities and create facilities in a way that visitors can have valuable experiences because sustainable development means providing the needs of the existing generation without weakening the ability of future generations to meet their needs $[1,4,6,7]$.

The method of sustainable development is important in tourism planning because tourism is mainly based on attractions and activities that are related to natural environment, historical heritage and patterns of cultural regions. If these resources get harmed or destroyed, tourist resorts cannot attract tourists, and tourism will not be successful [8]. Moreover, poor health conditions decrease economic and social benefits of tourism.

The main objective in the development of sustainable tourism is to provide reasonable methods to utilize natural and human resources and prevent non-scientific use of these resources. The development of sustainable tourism has two aspects of "protection of environment and resources and cultural heritage of societies. Following the Earth Summit in 1992 in Rio de Janeiro that asked the governments to minimize the loss and damage to the environment, they reached an agreement on the agenda of the meeting 21 (plans for 21th century). In fact, the agenda contained a set of detailed action plans that determined each country's role in achieving sustainable development. Therefore based on agenda 21, international organizations of tourism "Agenda 21 for Tourism" was released; it reminded the need to recognize the role of tourism in the appropriate development process and the necessity for practical plans for tourism organizations in order to activate the principles of sustainable tourism towards sustainable development [7, 9-11]. Following this conference, the World Tourism Organization (WTO) started some activities and defined development of sustainable tourism as "sustainable tourism development fulfills the needs of present tourists and host regions and maintains the opportunities of future generations." Sustainable tourism development manages all resources in a way that it fulfills economic, social and aesthetic needs and maintains cultural interactions, ecological processes and biodiversity and supports systems of environment [12-15]. Perez et al. in Cuban examined sustainable tourism in towards sustainable development [16]. Blancas et al. [9] and Lozano- Oyola et al. [17] in Spain, also, Blancas et al. [18] in coastal areas of Andalusian (Spain) determined level of sustainable tourism using sustainability indicators. Durovic and Loverentjev presented sustainable tourism indicators generally [19]. Xu and Fox in China and UK checked tourism and sustainable development [20]. It is necessary to achieve sustainable tourism by identifying indicators of sustainable tourism in its current status and analyzing the tourism situation and its consequences and effects on the environmental health, society and economy scientifically and carefully $[9,16]$. Concerning the above mentioned issues, the sustainability or non-sustainability of tourism elements was examined according to principles and criteria for sustainable tourism and by adopting appropriate policies for it.

The first purpose of this study was to achieve the appropriate set of indicators for sustainable tourism (especially considering the importance of the environmental health and sustainable development). Moreover, the second goal of this study was to make composite indicator of assessment of sustainable tourism in selected tourist cities of Kerman Province (Fig. 1). This way increased the users' ability to analyze and interpret it practically.

The innovative aspect of this study was to determine the combined indicator in social, economic and environmental aspects; in addition to providing a stable compound index, this indicator was analyzed using linear programming models. Using the Delphi method, which is dependent on field studies, was another aspect of innovation in this research.

\section{Methods}

This cross-sectional study was conducted in 2015 at selected tourist cities of Kerman Province (Kerman, Bam, Jiroft, Rafsanjan, Sirjan and Zarand); these cities were selected due to their historical context, their abundance of natural resources and their more touristic areas compared to other cities. In addition, based on the criteria presented by WTO and other experts, evaluation criteria for operating indicators were 1 - being relevant to the subject, 2 - data access (collecting and processing capacity) 3information validity, 4- clearness and understandability for users, and 5- the comparability over time and across jurisdictions or regions $[9,15,18,21]$. The quantitative data collected through documentary-library methods and statistical yearbooks of Kerman in 2013 required qualitative information by Delphi method and a questionnaire. To design a questionnaire, a large number of sustainable tourism indicators were collected in environmental health, environmental sustainability and social and economic issues by reviewing previous studies. Then, these indicators were localized by experts and professionals opinions and Delphi method through 90 university professors, managers, researchers in the field of tourism and environmental health in cities of Kerman province in three environmental health, social and economic domains (Tables $1,2,3)$ and were scored from 0 to $10(0$, the minimum and 10 , the maximum score and significance, for qualitative indicators) [16]. Validity was determined by experts, and stability was analyzed using Cronbach's alpha coefficient [22]. In the first stage (after completing the questionnaires and data collection), composite indicator of sustainable tourism was measured. 


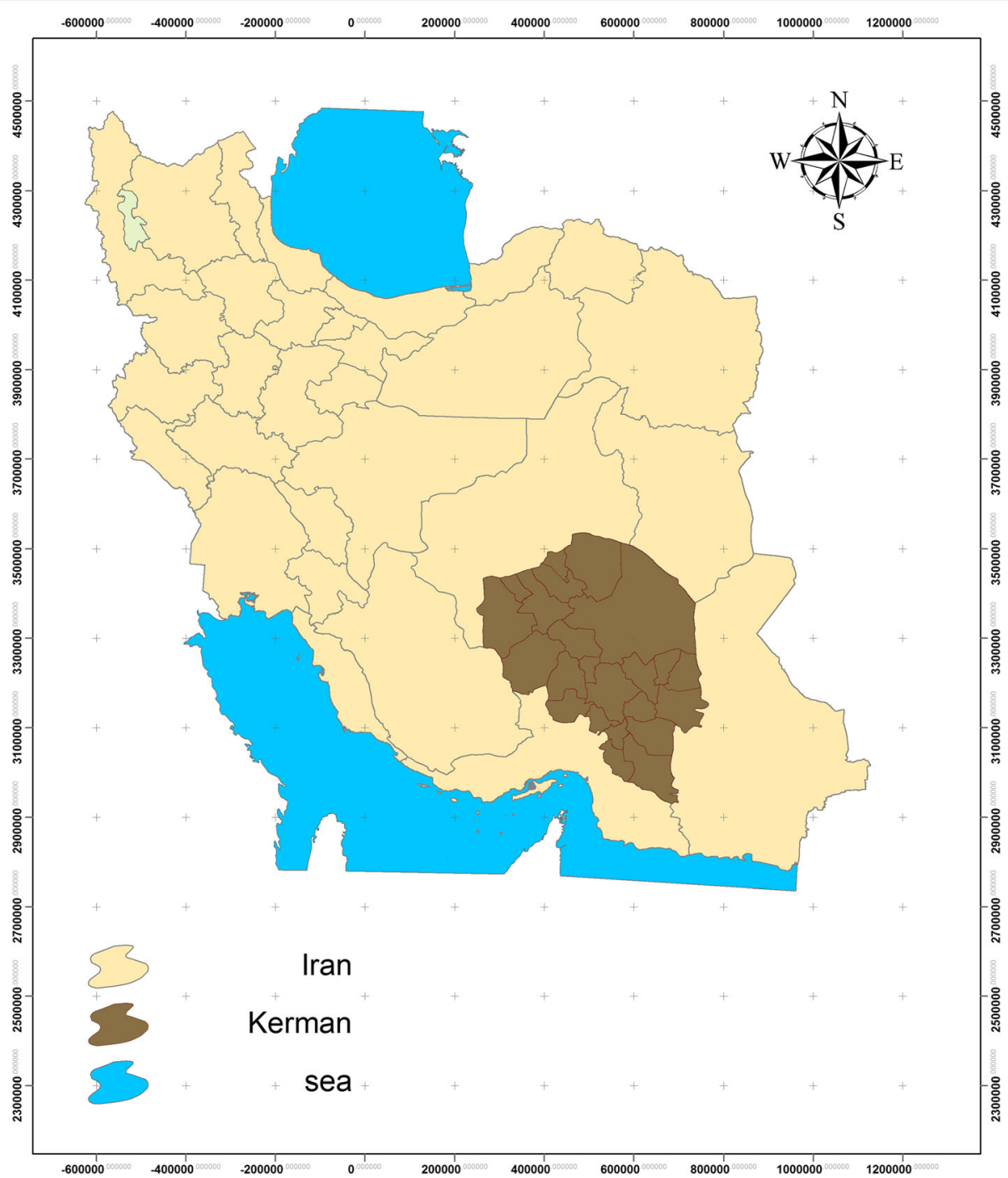

Fig. 1 Geographical position of study area

\section{Composite indicator of sustainable tourism}

Composite indicator of sustainable tourism was calculated using the principal component analysis (PCA) defined as follows; $\mathrm{N}$ is the destination and $\mathrm{J}$ is the main factor that had indicator with $I_{i j}$ value. At first step, indicators were presented and in the second step the value of each indicator was calculated (quantitative indicators by existing information and data and qualitative indicators using experts' opinions). In the third step, indicators were normalized using Eq. $1[9,16]$ :

$$
I N_{i j}=\frac{I_{i j}-\min }{\max -\min }
$$

It caused all values to be between 0 and 1 and did not affect the results. When the system became normal, finally Eq. 2 was used to make the composite indicator:

$$
D P C_{i}=\sum_{j=1}^{q}\left[V E_{j}\left(\sum_{i=1}^{p} I N_{i j}\left|\operatorname{Corr}_{j i}\right|\right)\right]
$$

$\mathrm{i}=1, \ldots, \mathrm{n}$, where $\mathrm{n}$ is the number of observations, $\mathrm{p}$ is the number of main indicators, $\mathrm{q}$ is the number factors and main selected component, $\mathrm{VE}_{\mathrm{j}}$ is the explained variance by jth component, $\operatorname{corr}_{\mathrm{ij}}$ is correlation between ith indicator and jth component. $\mathrm{IN}_{\mathrm{ij}}$ is the value of normal indicator and finally calculating $\mathrm{DPC}_{\mathrm{i}}$ (distance-principal component) that the value more than $\mathrm{DPC}_{\mathrm{i}}$ shows the higher sustainability in each dimension. The composite indicator of sustainable tourism is easily interpretable so it did not need to understand the complex computing relationship. 
Table 1 Environmental and environmental health indicators of sustainable tourism

\begin{tabular}{|c|c|c|c|}
\hline \multicolumn{2}{|l|}{ Main factor } & \multirow{2}{*}{$\begin{array}{l}\text { Indicator } \\
\text { The percent of the local people who have access to clean } \\
\text { and healthy water }\end{array}$} & \multirow{2}{*}{$\begin{array}{l}l_{i j}(\text { sign } \\
l_{i 1}(+)\end{array}$} \\
\hline Environmental health & Access to clean water & & \\
\hline & Water quality of tourism regions & $\begin{array}{l}\text { Quality evaluation of water of tourism regions (water pollution) } \\
(0-10)\end{array}$ & $\mathrm{I}_{\mathrm{i} 2}(+)$ \\
\hline & Waste produced by the tourism sector & Waste per capita (daily) & $\mathrm{I}_{\mathrm{i} 3}(-)$ \\
\hline & Noise pollution & Noise pollution & $\mathrm{I}_{\mathrm{i} 4}(-)$ \\
\hline & Producing of greenhouse gases (air pollution) & Annual emissions of greenhouse gases per capita & $\mathrm{I}_{\mathrm{i} 5}(+)$ \\
\hline & Environmental health (other factors) & Tourists evaluation of environmental health (0-10) & $\mathrm{I}_{\mathrm{i} 6}(+)$ \\
\hline & Environmental damages & People imagination from tourism environmental damages (0-10) & $\mathrm{I}_{\mathrm{i} 7}(-)$ \\
\hline \multicolumn{2}{|c|}{ protected natural regions } & The percentage of protected natural regions/total natural regions & $\mathrm{I}_{\mathrm{i} 8}(-)$ \\
\hline \multicolumn{2}{|c|}{ Ecological assessment of natural resources } & Biodiversity and species diversity of flora and fauna (per unit area) & $\mathrm{I}_{\mathrm{ig}}(-)$ \\
\hline \multicolumn{2}{|c|}{ Energy consumption in tourism sector } & Energy consumption daily (per capita) & $\mathrm{l}_{\mathrm{i} 10}(-)$ \\
\hline \multicolumn{2}{|c|}{ Water consumption in tourism sector } & Water consumption daily (per capita) & $\mathrm{I}_{\mathrm{i} 11}(-)$ \\
\hline \multicolumn{2}{|l|}{ Construction in region } & Construction density in area unit & $\mathrm{l}_{\mathrm{i} 12}(+)$ \\
\hline \multicolumn{2}{|l|}{ Erosion } & The rate of region erosion & $\mathrm{l}_{\mathrm{i} 13}(+)$ \\
\hline \multicolumn{2}{|l|}{ Natural landscapes } & The percentage of the region's natural landscapes & $\mathrm{I}_{\mathrm{i} 14}(+)$ \\
\hline \multicolumn{2}{|c|}{ Diversity of natural attractions } & The number of natural attractions to region area & $\mathrm{I}_{\mathrm{i} 15}(-)$ \\
\hline \multicolumn{2}{|c|}{ Agricultural level of region } & The percentage of agricultural land to total region area & $\mathrm{I}_{\mathrm{i} 16}(-)$ \\
\hline \multicolumn{2}{|l|}{ Intensity of tourism use } & The number of tourists in region unit area & $\mathrm{I}_{\mathrm{i} 17}(-)$ \\
\hline \multicolumn{2}{|c|}{ Disserted villages of region } & Disserted villages/total number of villages & $\mathrm{I}_{\mathrm{i} 18}(+)$ \\
\hline \multicolumn{2}{|c|}{ Intensity of natural resources use } & The number of tourists in protected region unit area & $\mathrm{I}_{\mathrm{i} 19}(+)$ \\
\hline \multicolumn{2}{|c|}{ Planning and environmental management } & An environmental administrative unit & $\left.(+)\right|_{i 20}$ \\
\hline \multicolumn{2}{|c|}{ environmental awareness level } & Assessment of promoting environmental awareness (0-10) & $\mathrm{I}_{\mathrm{i} 21}(-)$ \\
\hline \multicolumn{2}{|c|}{$\begin{array}{l}\text { Protection of natural resources and } \\
\text { destinationcultural heritage }\end{array}$} & Budget of cultural heritage-historical (per capita) & $\mathrm{I}_{\mathrm{i} 22}(+)$ \\
\hline \multicolumn{2}{|l|}{ Vegetation } & Percentage of the region vegetation & $\mathrm{I}_{\mathrm{i} 23}(+)$ \\
\hline \multicolumn{2}{|l|}{ Rare plant species } & The number of rare plant species (per unit area) & $\mathrm{I}_{\mathrm{i} 24}(+)$ \\
\hline \multicolumn{2}{|l|}{ Vegetation } & The diversity of plant species (per unit area) & $\mathrm{l}_{\mathrm{i} 25}(+)$ \\
\hline \multicolumn{2}{|l|}{ Rare animal species } & Rare animal species (per unit area) & $\mathrm{I}_{\mathrm{i} 26}(+)$ \\
\hline \multicolumn{2}{|c|}{ Diversity of animal species } & The diversity of animal species (per unit area) & $\mathrm{I}_{\mathrm{i} 27}(+)$ \\
\hline
\end{tabular}

Using made DPC indicator, the general sustainability indicator was analyzed in the next step by maximizing the target function for each destination by linear programming [16]:

$$
L P D P C_{i}=\operatorname{Max}_{w} \sum_{j=1}^{d} w_{j}^{i} D P C_{i j}
$$

Subject to:

$$
\begin{aligned}
& \sum_{j=1}^{d} w_{j}^{i} D P C_{i j} \leq 1 \quad i=1, \ldots, n w_{j}^{i} D P C_{i j} \geq \omega_{i} i=1, \ldots, n j \\
& \quad=1, \ldots, d w_{j}^{i} \geq 0 \quad j=1, \ldots, d
\end{aligned}
$$

Where $w_{j}^{i}$ are the weights for the observations $\mathrm{i}, \mathrm{d}$ is the number of tourism dimension in this study: social, economic and environmental aspect environmental health, $D P C_{i j}$ is the sustainable indicator in tourism dimension (calculated by Eq. 2. represents the jth dimension indicator for the ith observation) in tourism destination. $\omega_{i}$ is a real number (the minimum allowed weight provided by experts). This restriction caused all aspects (dimensions) of sustainable tourism to be considered. The advantage of this method was that the weights were determined by programming model and their views were not involved. $L P D P C_{i}$ (Linear programming distance-principal component). The indicator value $\left(L P D P C_{i}\right)$ was between zero and one [16]. Number one represented the best and the most stable situation and zero represented the worst stable situation. $L P D P C_{i}$ was calculated with the aim of maximizing the stability at each destination by using $\mathrm{DPC}_{\mathrm{ij}}$ indicator, accordingly, destinations could be 
Table 2 Social indicators of sustainable tourism

\begin{tabular}{|c|c|c|}
\hline Main factor & Indicator & $l_{i j}(\operatorname{sign})$ \\
\hline Sport services & Sport gym per capita & $(+) I_{i 28}$ \\
\hline Health and hygiene services & Hospitals and clinic per capita & $\left.(+)\right|_{i 29}$ \\
\hline Transportation services & Transportation vehicle per capita & $(+) I_{i 30}$ \\
\hline Financial services & Bank per capita & $(+) I_{i 31}$ \\
\hline Pharmaceutical Services & Pharmacy per capita & $\left.(+)\right|_{i 32}$ \\
\hline Tourism benefits & Distribution of tourism benefits for locals (0-10) & $\left.(+)\right|_{i 33}$ \\
\hline Tourism benefits & Distribution of tourism benefits for tourists (0-10) & $\left.(+)\right|_{i 34}$ \\
\hline Tourism benefits & Distribution of tourism benefits for environment (0-10) & $\left.(+)\right|_{i 35}$ \\
\hline Tourism attention to & Number of agencies and tour centers in area (per capita) & $(+) I_{i 36}$ \\
\hline $\begin{array}{l}\text { Participation and cooperation of people } \\
\text { for tourism activities }\end{array}$ & $\begin{array}{l}\text { People motivation for participation and cooperation with } \\
\text { local tourism organization }(0-10)\end{array}$ & $(+) I_{i 37}$ \\
\hline $\begin{array}{l}\text { Participation and cooperation of } \\
\text { non-governmental organization } \\
\text { for tourism activities }\end{array}$ & $\begin{array}{l}\text { The motivation of non-governmental organization for participation } \\
\text { in local tourism activities }(0-10)\end{array}$ & $\left.(+)\right|_{i 38}$ \\
\hline Management of tourism activities & Assessment Management of cultural tourism activities in the region (0-10) & $\left.(+)\right|_{i 39}$ \\
\hline Management of tourism activities & Assessment Management of ecotourism activities in the region (0-10) & $\left.(+)\right|_{i 40}$ \\
\hline Management of tourism activities & Assessment Management of agricultural tourism activities in the region (0-10) & $\left.(+)\right|_{i 41}$ \\
\hline Management of tourism activities & Tourism activities share in different economic sectors & $\mathrm{I}_{i 42}(+)$ \\
\hline Tourism share in destination economy & Safety assessment of destination by tourists $(0-10)$ & $\left.(+)\right|_{i 43}$ \\
\hline Tourists satisfaction from region safety & The per capita of region safety equipment (ambulance, road emergency) & $\mathrm{I}_{i 44}(+)$ \\
\hline Tourists satisfaction from region safety & Assessment the tension rate between tourists and residents $(0-10)$ & $\mathrm{I}_{i 45}(-)$ \\
\hline Tourists satisfaction from region safety & The number of recorded crimes in the region (per capita) & $\mathrm{I}_{i 46}(-)$ \\
\hline $\begin{array}{l}\text { The role of } \mathrm{t} \text { law enforcement in providing } \\
\text { security for tourists }\end{array}$ & $\begin{array}{l}\text { Evaluation of military cooperation and local or governmental } \\
\text { law enforcement agencies to provide security for tourists }(0-10)\end{array}$ & $\mathrm{I}_{i 47}(+)$ \\
\hline National and regional advertising & Awareness and positive publicity in the tourism region $(0-10)$ & $\mathrm{I}_{i 48}(+)$ \\
\hline National and regional advertising & $\begin{array}{l}\text { Negative publicity for southern regions of the country } \\
\text { (southern cities of province) }(0-10)\end{array}$ & $\mathrm{I}_{\text {i49 }}(-)$ \\
\hline Protecting cultural heritage & Budget of region cultural heritage (per capita) & $\mathrm{l}_{i 50}(+)$ \\
\hline The rate of using cultural heritage & The number of tourists to Antiquities area and cultural heritage & $\mathrm{I}_{i 51}(-)$ \\
\hline $\begin{array}{l}\text { Holding cultural festivals to keep and } \\
\text { introduce customs }\end{array}$ & The number of cultural exhibitions (per capita) & $\left.(+)\right|_{i 52}$ \\
\hline Attention to sustainable tourism & Increasing attention of agencies to sustainable tourism (balanced) (0-10) & $\mathrm{l}_{i 53}(+)$ \\
\hline Attention to sustainable tourism & Increasing attention level of policy makers to sustainable tourism (0-10) & $\mathrm{I}_{i 54}(+)$ \\
\hline Attention to sustainable tourism & Tourists motivation for sustainable tourism (0-10) & $\mathrm{l}_{i 55}(+)$ \\
\hline Attention to sustainable tourism & Innovation for sustainable tourism (0-10) & $\mathrm{l}_{i 56}(+)$ \\
\hline Attention to sustainable tourism & $\begin{array}{l}\text { Changing attitudes toward environment and the importance of } \\
\text { protecting attractions }(0-10)\end{array}$ & $\mathrm{l}_{i 57}(+)$ \\
\hline Stability of population level & Instability level of the region's population & $\mathrm{I}_{i 58}(-)$ \\
\hline Young population & The percentage of young population of the region & $\mathrm{l}_{i 59}(+)$ \\
\hline old population & The percentage of old population of the region & $\mathrm{I}_{i 60}(-)$ \\
\hline The population density & The number of people per unit area & $\mathrm{I}_{i 61}(-)$ \\
\hline Stability of population level & The net rate of region migration & $\mathrm{I}_{\mathrm{i} 22}(-)$ \\
\hline Stability of population level & Natural rate of population increase & $\mathrm{I}_{\text {i63 }}(-)$ \\
\hline The imposition of a foreign culture & The percentage of foreign population like Afghans in the region & $\mathrm{l}_{i 64}(-)$ \\
\hline Social tolerance capacity & tourists rate to the region's population (host community) & $\mathrm{I}_{i 65}(-)$ \\
\hline $\begin{array}{l}\text { The impact of social conditions on } \\
\text { longevity population }\end{array}$ & Life expectancy & $\mathrm{I}_{i 66}(+)$ \\
\hline
\end{tabular}


Table 2 Social indicators of sustainable tourism (Continued)

\begin{tabular}{|c|c|c|}
\hline The region income level & The income per capita & $\mathrm{I}_{\mathrm{i} 67}(+)$ \\
\hline $\begin{array}{l}\text { The family percentage using social utilities } \\
\text { in region }\end{array}$ & The family percentage using social utilities in region (electricity) & $\mathrm{l}_{i 68}(+)$ \\
\hline Understanding and cooperation & $\begin{array}{l}\text { Mutual understanding and cooperation of local people with } \\
\text { tourists }(0-10)\end{array}$ & $\mathrm{l}_{\text {i69 }}(+)$ \\
\hline Elderly care & Assessment of elderly care facilities in tourism regions $(0-10)$ & $\mathrm{l}_{i 70}(+)$ \\
\hline Children care & Assessment of children care facilities in tourism regions $(0-10)$ & $\mathrm{I}_{i 71}(+)$ \\
\hline Unemployment rate & Unemployment rate of region & $\mathrm{I}_{i 72}(-)$ \\
\hline Tourism impact on residents & $\begin{array}{l}\text { Local people imagination from services improvement because } \\
\text { of tourism }(0-10)\end{array}$ & $\mathrm{I}_{i 73}(+)$ \\
\hline Tourism impact on residents & $\begin{array}{l}\text { Local people imagination from the adverse effects of tourism on } \\
\text { local people's lifestyle }(0-10)\end{array}$ & $\mathrm{I}_{i 74}(-)$ \\
\hline Tourism impact on residents & $\begin{array}{l}\text { Local people imagination from tourism impact on avoiding local } \\
\text { people exit from region }(0-10)\end{array}$ & $\mathrm{I}_{775}(+)$ \\
\hline Tourism impact on residents & $\begin{array}{l}\text { Local people imagination from life quality improvement because of } \\
\text { tourism increase in region }(0-10)\end{array}$ & $\mathrm{I}_{i 76}(+)$ \\
\hline Tourists impression of quality of public services & $\begin{array}{l}\text { Tourists impression of quality of public services (accommodation and } \\
\text { transport facilities) (0-10) }\end{array}$ & $\mathrm{l}_{i 77}(+)$ \\
\hline Hospitality and willingness to receive tourists & $\begin{array}{l}\text { Hospitality assessment and willingness to receive tourists in the local } \\
\text { community }(0-10)\end{array}$ & $\mathrm{l}_{i 78}(+)$ \\
\hline $\begin{array}{l}\text { Conservation, reconstruction and restoration } \\
\text { of monuments and cultural heritage }\end{array}$ & $\begin{array}{l}\text { Conservation budget, reconstruction and restoration of monuments } \\
\text { and cultural heritage (per capita) }(0-10)\end{array}$ & $\mathrm{I}_{i 79}(+)$ \\
\hline Environment improvement & Green space per capita & $\mathrm{l}_{880}(+)$ \\
\hline Women's rights & Evaluation of improving women's rights (0-10) & $\mathrm{l}_{881}(+)$ \\
\hline Labor rights and social security & Evaluation of improving labor rights and social security $(0-10)$ & $\mathrm{l}_{882}(+)$ \\
\hline Education level & Universities and higher education centers & $\mathrm{I}_{883}(+)$ \\
\hline Education level & Population literacy rate & $\mathrm{l}_{884}(+)$ \\
\hline Variety of handicrafts & $\begin{array}{l}\text { Evaluation of the number and variety of handicrafts to attract } \\
\text { tourists }(0-10)\end{array}$ & $\mathrm{l}_{885}(+)$ \\
\hline Cultural-historic background & The number of cultural-historic sites (per unit area) & $\mathrm{l}_{i 86}(+)$ \\
\hline Cultural-historic background & Local-traditional cultures & $\mathrm{l}_{i 87}(+)$ \\
\hline
\end{tabular}

ranked and the highest and lowest sustainable places could be identified.

Gams, SPSS, Excel software and statistical methods were used to analyze data.

\section{Results}

Cronbach's alpha coefficient (stability) was calculated 0.9 , so stability was acceptable and confirmed validity questionnaires.

Sustainable results in all tourism dimensions (environmental health, social and economic) were presented in Table 4 and Fig. 2; they showed all aspects of the low level of sustainability ( 0 was the worst situation and 1 was the best conditions) and environmental dimension (so environmental health) of sustainability was the most inappropriate situation. Using a linear programming model and experts' survey, results of sustainability in tourism destinations (6 cities under study) were shown in Table 5. Moreover, Fig. 3; compared the sustainability of tourism destinations.

\section{Discussion}

Tourists travel to tourist destinations or regions that have both regional attractions and life, financial and health security. Although tourists travel with different purposes, they consider public health a very important issue and prefer to travel to areas with safer environment. Tourist regions that have air and water pollution cannot retain the tourists' health and therefore cannot attract tourists and will be far away from the sustainable development goals. Water pollution is a major issue because contaminated water disrupts the balance of the ecosystem and brings irreparable damages to it. The quality of drinking water has a significant impact on public health. One of the major concerns of tourists is water pollution because of its toxic effects on humans, animals and plants (and 
Table 3 Economic indicators for sustainable tourism

\begin{tabular}{|c|c|c|}
\hline Main factor & Indicator & $l_{i j}(\operatorname{sign})$ \\
\hline Tourism demand of region & Number of tourist & $\mathrm{I}_{888}(+)$ \\
\hline Tourist length of stay & Average of length of stay & $\mathrm{l}_{i 89}(+)$ \\
\hline Tourism income & The expense of one night stand of tourists & $\mathrm{I}_{i 90}(+)$ \\
\hline Income distribution & ini coefficient & $\mathrm{l}_{i 91}(+)$ \\
\hline Tourism satisfaction & The satisfaction of domestic tourists from the region (0-10) & $\mathrm{I}_{i 92}(+)$ \\
\hline Tourism satisfaction & The satisfaction of foreigner tourists from the region $(0-10)$ & $\mathrm{l}_{i 93}(+)$ \\
\hline Tourism satisfaction & $\begin{array}{l}\text { Positive imagination of tourists from the relationship between } \\
\text { quality and services price in the region (0-10) }\end{array}$ & $\mathrm{l}_{994}(+)$ \\
\hline Tourism satisfaction & $\begin{array}{l}\text { The imagination of tourists from the relationship between quality } \\
\text { and accommodation price }(0-10)\end{array}$ & $\mathrm{l}_{995}(+)$ \\
\hline Tourism satisfaction & $\begin{array}{l}\text { The imagination of tourists from the relationship between quality } \\
\text { and restaurant price }(0-10)\end{array}$ & $\mathrm{l}_{996}(+)$ \\
\hline Tourism satisfaction & $\begin{array}{l}\text { Assessment work quality of staff in the tourism sector (hotels, } \\
\text { restaurants, etc.) (0-10) }\end{array}$ & $\mathrm{l}_{\text {ig7 }}(+)$ \\
\hline Tourism satisfaction & $\begin{array}{l}\text { Tourist's satisfaction from protected collections and regional } \\
\text { cultural collection (0-10) }\end{array}$ & $\mathrm{l}_{998}(+)$ \\
\hline Tourism information transparency & Tourists assessment of transparency of tourism information (0-10) & $\mathrm{I}_{i 99}(+)$ \\
\hline Currency rate & he percentage of currency rate changes (foreigner tourists) & $\mathrm{I}_{i 100}(+)$ \\
\hline Communication conditions & Telecommunication and post facilities (per capita) & $\mathrm{l}_{i 101}(+)$ \\
\hline Communication conditions & Online communication (ADSL) (per capita) & $\mathrm{l}_{\mathrm{i102}(+)}$ \\
\hline Tourism planning & Evaluation of tourism planning in region $(0-10)$ & $\mathrm{I}_{i 103}(+)$ \\
\hline $\begin{array}{l}\text { Government participation with non-governmental } \\
\text { organization }\end{array}$ & $\begin{array}{l}\text { Evaluation of government participation with non-governmental } \\
\text { organization about local tourism activities }(0-10)\end{array}$ & $\mathrm{l}_{j 104}(+)$ \\
\hline People participation rate and local organization & $\begin{array}{l}\text { Evaluation of people participation rate and local organization } \\
\text { for providing and executing tourism plans }(0-10)\end{array}$ & $\mathrm{l}_{i 105}(+)$ \\
\hline $\begin{array}{l}\text { Providing official residence of tourism such as } \\
\text { hotels and inns }\end{array}$ & Hotel and motel per capita & $\mathrm{I}_{i 106}(+)$ \\
\hline $\begin{array}{l}\text { Providing tourism official residence with high } \\
\text { quality }\end{array}$ & Three, four and five star hotels per capita & $\mathrm{I}_{i 107}(+)$ \\
\hline $\begin{array}{l}\text { Providing restaurants with high quality food } \\
\text { and services }\end{array}$ & Restaurant per capita & $\mathrm{I}_{i 108}(+)$ \\
\hline Information access & Information centers for tourists (per capita) & $\mathrm{I}_{i 109}(+)$ \\
\hline Information access & Regional tourism websites & $\mathrm{I}_{i 110}(+)$ \\
\hline Information access & The number of newspapers and local magazines & $\mathrm{I}_{i 111}(+)$ \\
\hline Information access & Assessment tourism pace in national and regional region $(0-10)$ & $\mathrm{I}_{i 1212}(+)$ \\
\hline Tourism seasonal demand & The ratio of low season tourists to high season & $\mathrm{I}_{i 113}(+)$ \\
\hline Number of employed staff in tourism sector & Number of hotel employed staff & $\mathrm{I}_{i 114}(+)$ \\
\hline $\begin{array}{l}\text { Relative share of tourism employment to } \\
\text { total employment in destination }\end{array}$ & Hotel employment to total employment & $\mathrm{I}_{i 115}(+)$ \\
\hline Tourism employment & The percentage of employed women in tourism sector & $\mathrm{I}_{i 116}(+)$ \\
\hline Tourism employment & Local employment people in tourism sector & $\mathrm{l}_{i 117}(+)$ \\
\hline Generated employment in services sector & Service sector employed/total employment & $\mathrm{I}_{i 18}(+)$ \\
\hline Transportation services & Transportation equipment per capita & $(+) I_{i 119}$ \\
\hline Airport access & Having or not having airport & $\mathrm{I}_{i 120}(+)$ \\
\hline Highway access & Highway length/total area of region & $\mathrm{l}_{i 121}(+)$ \\
\hline Road access & Road length/total area of region & $\left.(+)\right|_{i 122}$ \\
\hline Railroad access & Having or not having railroad & $\mathrm{I}_{i 123}(+)$ \\
\hline The occupation rate of residential places & Average of occupation rate & $\left.(+)\right|_{i 124}$ \\
\hline
\end{tabular}


Table 3 Economic indicators for sustainable tourism (Continued)

\begin{tabular}{llll}
\hline Regional tourist attractions & The number of natural and historical attractions/region area & Total road length network/region area & $I_{i 125}(+)$ \\
Constructed roads in region & Budget of renovation and restoration of cultural heritage (per capita) & $I_{i 126}(+)$ \\
Protecting cultural heritage & Evaluation of access to required credit for tourism agencies $(0-10)$ & $I_{i 127}(+)$ \\
Access to required credit for tourism agencies & Evaluation of local people's views from the impact of tourism on \\
The impact of tourism on booming regional crafts & booming regional crafts $(0-10)$
\end{tabular}

subsequently food contamination). Water pollution contaminates the agricultural lands, crops and livestock, produces unhealthy food and threatens the public health. Improving water quality and reducing the pollution is important for two reasons both of which are essential in terms of tourism: 1. human health (residents and tourists) and 2. Environmental protection. Air pollution endangers human and animal health and even vegetation, causes erosion and threatens historic monuments and cultural heritage. In recent decades, air pollution and smog have become an environmental problem especially in big cities; nowadays, tiny dust particles have also worsened the situation. Therefore, it is necessary to consider air pollution seriously so as to boost sustainable tourism industry. It is obvious that areas with high pollution will not be chosen for tourism. Since tourists use fossil fuel (concerning high consumption of such fuels in Iran transportation system) for their transportation, the environment will be severely damaged. Noise pollution is also an important factor in tourism because increased noise can increase stress and cause severe crisis for people. Therefore, this indicator is considered an important factor influencing tourism because cities with high noise pollution cannot become target destinations for tourists who seek recreation and leisure. Municipal wastes and effluents, sewage and wastes destroy the appearance of cities and tourist regions and are the cause of increased air and water pollution. Thus, when the environmental management (such as wastewater management, waste water and waste disposal) is inefficient, the possibility of attracting tourists is low. It is a mutual relationship between

Table 4 Tourism dimensional (aspects) sustainability

\begin{tabular}{lllllcl}
\hline City & $\begin{array}{l}\text { Social } \\
\text { DPC }\end{array}$ & Rank & $\begin{array}{l}\text { Economic } \\
\text { DPC }\end{array}$ & $\begin{array}{c}\text { Rank } \\
\text { Environmental \& } \\
\text { Environmental } \\
\text { health DPC }\end{array}$ & Rank \\
\hline Kerman & 0.56 & 4 & 0.45 & 2 & 0.25 & 2 \\
Bam & 0.62 & 2 & 0.38 & 3 & 0.33 & 1 \\
Jiroft & 0.46 & 6 & 0.32 & 5 & 0.21 & 3 \\
Rafsanjan & 0.64 & 1 & 0.49 & 1 & 0.19 & 4 \\
Sirjan & 0.61 & 3 & 0.35 & 4 & 0.10 & 6 \\
Zarand & 0.49 & 5 & 0.32 & 5 & 0.16 & 5 \\
\hline
\end{tabular}

tourism and pollution; if there is high contamination in the area, it will endanger the health of tourists and residents and therefore tourists lose their intentions to travel to these regions. On the other hand, the mass presence of tourists (untrained and unmanaged) will increase the production of waste and increase air and water pollution. Therefore, it is necessary to consider a proper wastewater treatment system and a garbage collection system as indicators of sustainability. Soil erosion by water and wind reduces the soil fertility and soil structure degradation and permeability, creates ugly scenes, increases the likelihood of flooding and sediment production, harms the nature, the environment and the economy and reduces tourist attractions. It must be noted that most cities of Kerman have desert attractions in which erosion is completely obvious; this reduces tourism in these areas. The maintenance of biodiversity and health of plant and animal species lead to equitable distribution of biological resources between generations, and its sustainability can increase the livelihood opportunities of people from different ways like the ecotourism in a healthy environment. Tourism and biodiversity are interconnected; if we only look at it from the economical point of view, developing tourism without proper management is a threat to biodiversity of region; when we lose the health of species and biodiversity, the region will lose its capability of attracting tourists and their economic value creation. Also, preserving rare and endangered plant and animal species could attract ecotourism in a good way. Therefore, it is necessary to consider these factors in sustainable tourism. Different urban areas require the development of green space to be able to maintain their stability. Green spaces have ecological and environmental functions, partly deal with air pollution and improve their standard of living and tourism in which the density construction must also be taken into consideration to preserve the balance of nature. The green space per capita is one of the most important indicators of development of the societies in which the index of green space per capita must be considered in sustainability issue. The administrative environmental systems and improved management are essential to reduce the negative impacts of tourism activities. In 


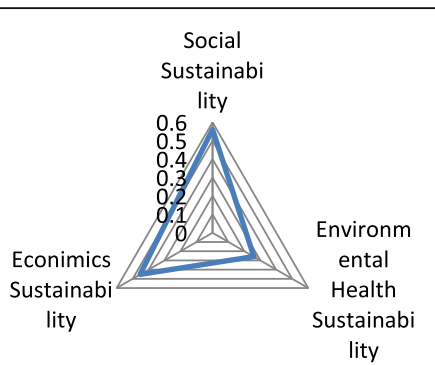

Kerman

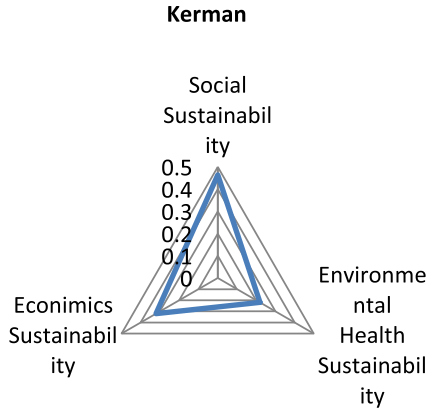

Jiroft

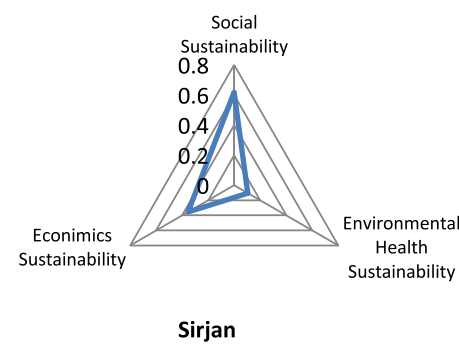

Sirjan

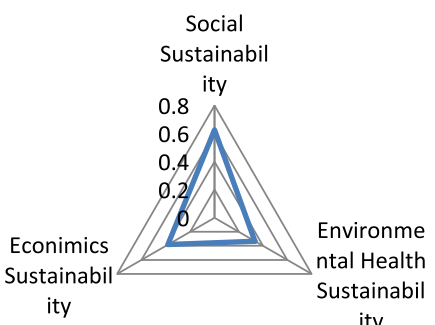

ity

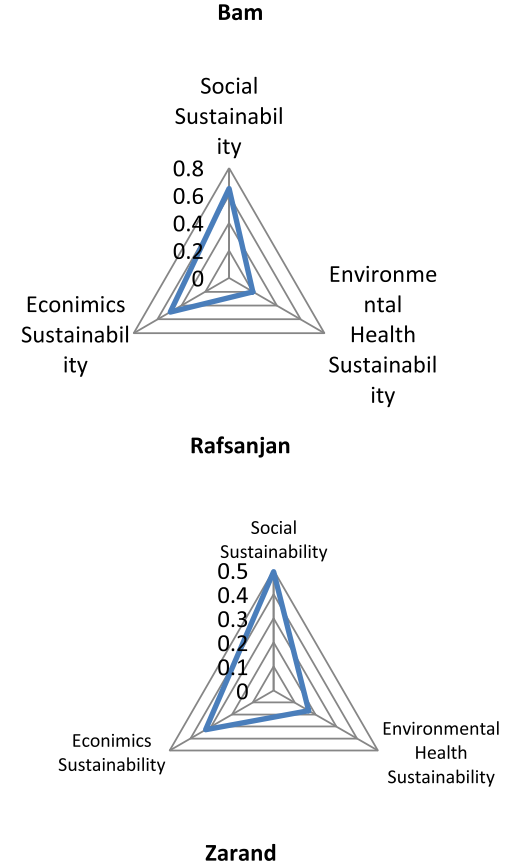

Fig. 2 Sustainability dimensions of sustainable tourism

general, vitality of ecosystem is a competitive factor attracting tourists in different tourism destinations.

The present study showed that unfortunately the opportunities for tourism were not used appropriately in the city and tourist destinations concerning sustainable development goals. Having multiple factors and tourist attractions, Kerman couldn't attract many tourists, and these cities were not able to have a proper tourist attraction. Moreover, most indicators of these cities did not have appropriate levels (average sustainability 0.5).

Table $\mathbf{5}$ Tourism sustainability destinations

\begin{tabular}{|c|c|c|c|c|}
\hline City & $\begin{array}{l}\text { Weight average } \\
\text { (level sustainability) }\end{array}$ & $\begin{array}{l}\text { Sustainability } \\
\text { ranking }\end{array}$ & $\angle P D P C_{i}$ & $\begin{array}{l}\text { Sustainability } \\
\text { ranking }\end{array}$ \\
\hline Kerman & 0.4391 & 3 & 0.4166 & 3 \\
\hline Bam & 0.4469 & 2 & 0.4347 & 2 \\
\hline Jiroft & 0.3347 & 6 & 0.3546 & 5 \\
\hline Rafsanjan & 0.4582 & 1 & 0.4761 & 1 \\
\hline Sirjan & 0.3779 & 4 & 0.3588 & 4 \\
\hline Zarand & 0.3402 & 5 & 0.3521 & 6 \\
\hline
\end{tabular}

Therefore, these indicators were the tools to analyze the strengths and weaknesses of tourist attraction and the sustainable tourism levels in these cities. Thus, it could be concluded that the social dimension had the highest sustainability rank, while the environmental dimension had the lowest one; it showed low importance of the environmental dimension among these destinations. The

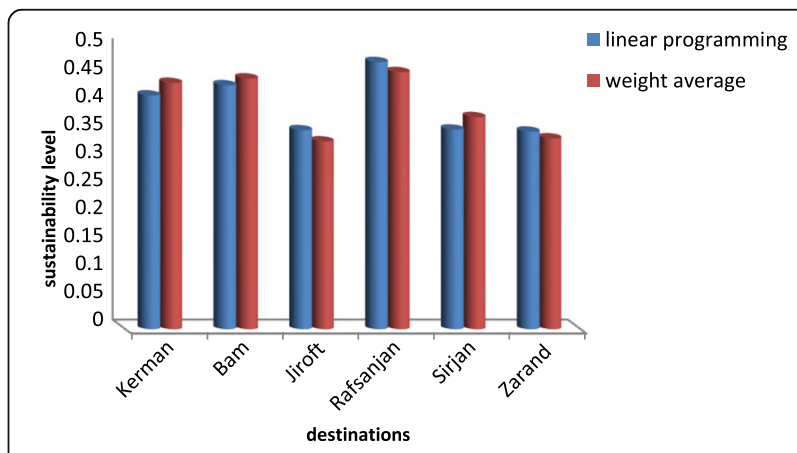

Fig. 3 The sustainability of tourism destinations by weight average and linear programming method 
results of this study were inconsistent (as expected) with the results of studies conducted by Blancas et al. [9], perez et al.[16] and Lozano-Oyola et al. [17] due to strong sustainable development, environmental protection and health issues in developed countries compared to the developing countries.

\section{Conclusion}

Based on the studies conducted in this area, sustainable tourism has various environmental health, social - cultural and economic aspects. Therefore, to assess sustainable tourism in intended cities according to the sustainable development goals, it is necessary to consider an inclusive and comprehensive system of parameters and use this analysis deeply in the sustainable tourism. The results indicated that none of the intended cities had acceptable sustainable levels, and that they were far from it. Moreover, they revealed that the environmental aspect was not considered seriously and was much worse than other aspects. One of the essential factors was giving free environmental services and nature to human beings that led to inappropriate overuse, destruction and reduction of the levels of environmental health and environmental sustainability. Having found the ranking of cities by these indicators, the sustainable tourism of cities can improve using good policies and plans made by policy-makers and managers. If the environmental health aspect is taken into more account, the sustainability level will increase significantly. The relationship between tourism and the environmental health should be organized toward sustainable development so that we can have stable environment in the long term and we should not let tourism destroy natural resources and damage job creation in future. Since most data was quantitative in making composite indicators, the reliability and comparability of destinations would increase. Therefore, this method is one of the most appropriate methods which can be used to analyzed sustainable tourism, sustainable health environment and environment of destinations and can be a way to achieve sustainable development.

\section{Abbreviations}

DPC: Distance- principal component; LPDPC: Linear programming distanceprincipal component; PCA: Principal component analysis; WTO: World tourism organization

\section{Acknowledgements \\ This research was part of a Ph.D dissertation of the first author and the authors would like to express their thanks to Tourism and environmentalists} experts' guidance.

\section{Funding}

Not applicable.

\section{Availability of data and materials}

The authors do not wish to share their data. All the necessary data have been mentioned in the paper. If other researchers need our data for their studies, they can contact with first Author via email.

\section{Authors' contributions}

$M Z$ was the main investigator and has participated in all stages of the study (design of the study, collected the data, analyzing of data and manuscript preparation). MM was an advisor of the study and participated in the intellectual helping in different stages of the study. MRZM supervised the study and performed data collection and carried out technical analysis. AMJ and $\mathrm{HMB}$ were advisors of the study and participated in the intellectual helping in different stages of the study. All authors read and approved the final manuscript.

\section{Competing interests}

The authors declare that they have no competing interests.

Consent for publication

Not applicable.

Ethics approval and consent to participate

Not applicable.

\section{Publisher's Note}

Springer Nature remains neutral with regard to jurisdictional claims in published maps and institutional affiliations.

\section{Author details}

${ }^{1}$ Economics of natural resources and Environment, Shahid Bahonar University of Kerman, Kerman, Iran. ${ }^{2}$ Environmental Health Engineering Research Center and Department of Environmental Health, School of Public Health, Kerman University of Medical Sciences, Kerman, Iran. ${ }^{3}$ Economics of Natural Resources and Environment, Shahid Bahonar University of Kerman, Kerman, Iran. ${ }^{4}$ International Economics, Shahid Bahonar University of Kerman, Kerman, Iran. ${ }^{5}$ Agricultural Economics-agricultural policy and development, Shahid Bahonar University of Kerman, Kerman, Iran.

Received: 18 June 2016 Accepted: 8 March 2017

Published online: 28 March 2017

\section{References}

1. Ebrahimzadeh E, Aghasizadeh A. Analysis of factors affecting the development of tourism in coastal areas Chabahar Using SWOT Strategic. J Urban Reg Stud Res. 2009;1(1):107-28. originate Persian.

2. Moreno A, Amelung B. Climate change and tourist comfort on Europe's beaches in summer: a reassessment. Coast Manage. 2009;37:550-68.

3. Samat N, Harun N. Urban development pressure: challenges in ensuring sustainable tourism development in langkawi island. Procedia Soc Behav Sci. 2013;91:385-94.

4. Choi HC, Sirakaya E. Sustainability indicators for managing community tourism. Tourism Manage. 2006;27:1274-89.

5. Kim K. The effects of tourism impacts upon quality of life residents in the community. Virginia: Virginia Polytechnic Institute and State University Blacksburg; 2002.

6. Mason M C, derven Der B J. Sustainable Tourism Development in Rural Areas, The case if the Dolomite Basin, Italy; 2002

7. Fennel D A. Ecotourism. 2rd ed. Rutledge, London; 2006.

8. Holden A. Tourism and environment. 2rd ed. Routledge, London; 2008

9. Blancas FJ, Lozano-Oyola M, Gonzalez M, Guerrero FM, Caballero R. How to use sustainability indicators for tourism planning: The case of rural tourism in Andalusia (Spain). Sci Total Environ. 2011;412:28-45.

10. Jayawardena C, Patterson J, Choi D, Ryan B. Sustainable tourism development in Niagara; Discussions, theories and insights. Int J Contemp Hosp M. 2008;20(3):258-77.

11. Ko TG. Development of a tourism sustainability assessment procedure: a conceptual approach. J Tourism Manage. 2005;26:431-45.

12. Abdullaev A. Rural Tourism and Sustainable Development in Hookkaido, Candidate for the Degree of Master/Division of Urban and Environmental Engineering; Hokkaido University. Sapporo. 2007;162-65.

13. World Tourism Organization. Indicators of Sustainable Development for Tourism Destinations. A Guidebook. WTO, Madrid; 2004.

14. World Tourism Organization. Tourism: The Year 2000 and Beyond Qualitative Aspects, Discussion paper. WTO; 1993. 
15. Blancas FJ, Caballero R, Gonzalez M, Lozano-oyola M, Perez F. Goal Programming synthetic indicator: an application for sustainable tourism in Andalusian Coastal countries. Ecol Econ. 2010;69:2158-72.

16. Perez V, Guerrero F, Gonzalez M, Perez F, Caballero R. Composite indicator for the assessment of sustainability: The Case of Cuban nature-based tourism destinations. Ecol Indic. 2013;29:316-24.

17. Lozano- Oyola M, Blancas FJ, Gonzalez M, Caballero R. Sustainable tourism indicators as planning tools in cultural destinations. Ecol Indic. 2012;18:659-75.

18. Blancas FJ, Gonzalez M, Lozano-Oyola M, Perez F. The assessment of sustainable tourism: application to Spanish coastal destinations. Ecol Indic. 2010;10:484-92

19. Durovic M, Loverentjev S. Indicators of sustainability in cultural tourism. The Macrotheme Rev (A multidisciplinary journal of global macro trends). 2014; 3(7): 180-189

20. Xu F, Fox D. Modeling attitudes to nature, tourism and sustainable development in national parks: A survey of visitors in China and UK. Tourism manage. 2014;45:142-58.

21. Roknaldin Eftekhari A, Mahdavi D, Poortaheri M. Localization process of sustainable development indicators of rural tourism in Iran, Rural Studies. 2010; 4: 1-41 (originate Persian).

22. Cronbach $\sqcup$. Coefficient alpha and the internal structure of tests. Psychometrical. 1951;16:297-334.

Submit your next manuscript to BioMed Central and we will help you at every step:

- We accept pre-submission inquiries

- Our selector tool helps you to find the most relevant journal

- We provide round the clock customer support

- Convenient online submission

- Thorough peer review

- Inclusion in PubMed and all major indexing services

- Maximum visibility for your research

Submit your manuscript at www.biomedcentral.com/submit
Biomed Central 